\title{
Analysis of Effect of Protective Coatings on the Rate of Corrosion in Reinforced Concrete Sewers: Microscopic Study
}

\author{
Ahmad Ali ${ }^{1, a^{*}}$, Raheel Zafar ${ }^{2, b}$, Tayyaba Bibi ${ }^{3, c}$ \\ ${ }^{1}$ Department of Civil Engineering, Military college of Engineering, \\ National University of science and Technology, Civil Engineering, \\ Risalpur, KPK, Pakistan \\ ${ }^{2}$ Department of Civil Engineering, University of Engineering and Technology, \\ Peshawar, KPK, Pakistan \\ ${ }^{3}$ Department of Civil Engineering, \\ University of Engineering and Technology, \\ Peshawar, KPK, Pakistan \\ a*pc.ahmadali@gmail.com, b13jzciv0026@uetpeshawar.edu.pk, \\ cce.tayyaba@gmail.com
}

Keywords: Reinforced concrete sewers, sulphide attack, microbial induced corrosion, SEM, EDAX

\begin{abstract}
Microbial induced corrosion (MIC) in reinforced concrete (RC) sewers are increasing in occurrence and severity which is leading to significant economic losses. Being able to prevent or significantly reduce the rate of MIC in RC sewers will be of great help in finding a suitable sustainable solution. This study has investigated the effect of MIC; sulphide corrosion, on RC sewers through analytical techniques; scanning electron microscopy (SEM) and energy dispersive X-ray analysis (EDAX). The aim was to create a sustainable solution; protective epoxy coating (PEC), that will be capable of preventing or significantly reducing the MIC in RC sewers. The PEC based solution was able to significantly reduce the MIC in RC sewers. Furthermore, the test results also outlined that even in the coated sample, crown corrosion was more as compared to the corrosion of the submerged portion of the sample.
\end{abstract}

\section{Introduction}

Due to microbial induced corrosion (MIC) in sewers, billions of dollars per annum losses have been incurred worldwide on sewerage system (Wei et al. 2013; Zhang et al. 2008a; E hewayde et al. 2007); more than $\$ 50$ billion for rehabilitation purpose in Germany (Hewayde et al. 2006), almost $\$ 500$ million for treatment of corroded and degraded pipes in Los Angeles (Apté et al. 2015) and approximately $10 \%$ of the total sewage treatment cost for treating MIC of sewers in Flanders, Belgium (Zhang et al. 2008). MIC is an immense problem in RC sewers infrastructure due to complexity of multistage processes (Sulikowski \& Kozubal, 2016; Islander et al, 1992) that occurs externally (sulphate attack) and internally (sulphide corrosion) (Parande et al, 2006; Ling et al. 2014; Jiang et al. 2015, 2016; Dong, Shi, \& Liu, 2017). Soil containing high sulphate content attacks the surface of concrete externally while sulphate-reducing bacteria, below the water line, acted on the sewage internally (Kuliczkowska, 2016; Ling et al. 2014), produce hydrogen sulphide $\left(\mathrm{H}_{2} \mathrm{~S}\right)$ which enters into the moisture layer and converted into sulphuric acid $\left(\mathrm{H}_{2} \mathrm{SO}_{4}\right)$ (Sun et al. 2015; Parker, 1951) which attack the concrete matrix and continuously deteriorated the sewer internally (Y. Liu et al. 2015; Parker, 1947). Below is summarized sulphide corrosion phenomena is (Sharma et al., 2008; Wells et al. 2012):

$$
\begin{aligned}
& \text { Organic matter }+\mathrm{SO}_{4}{ }^{2-} \rightarrow \mathrm{H}_{2} \mathrm{~S}+\mathrm{CO}_{2} \\
& \mathrm{H}_{2} \mathrm{~S}+2 \mathrm{O}_{2} \rightarrow \mathrm{H}_{2} \mathrm{SO}_{4}
\end{aligned}
$$




$$
\begin{aligned}
& \mathrm{H}_{2} \mathrm{SO}_{4}+\mathrm{CaO} . \mathrm{SiO}_{2} .2 \mathrm{H}_{2} \mathrm{O} \rightarrow \mathrm{CaSO}_{4}+\mathrm{Si}(\mathrm{OH})_{4}+\mathrm{H}_{2} \mathrm{O} \\
& \mathrm{H}_{2} \mathrm{SO}_{4}+\mathrm{CaCO}_{3} \rightarrow \mathrm{CaSO}_{4}+\mathrm{H}_{2} \mathrm{CO} \\
& \mathrm{H}_{2} \mathrm{SO}_{4}+\mathrm{Ca}(\mathrm{OH})_{2} \rightarrow \mathrm{CaSO}_{4}+2 \mathrm{H}_{2} \mathrm{O}
\end{aligned}
$$

RC sewers are susceptible to heavy corrosion due to the sulphate content (Meyer \& Ledbetter, 1970; Gemert, 2001; Little et al, 2009) present in the sewage which ultimately compromise the integrity of structure and shorten the service life of sewers. The economy of the sewerage system adversely affected by the service life of RC sewers (O 'connell et al, 2010).

Various investigations at multi-stage of MIC has been done to understand the origin and prevention (Jiang et al. 2015; Grengg et al. 2018; Eštokova et al. 2012); mitigating the penetration of carbonation (De Muynck, Cox, Belie, \& Verstraete, 2008; Islander et al. 1992), interrupting the growth of Thiobacillus species (sulphate-reducing bacteria) (Okabe et al. 2007), controlling the production of $\mathrm{H}_{2} \mathrm{SO}_{4}$ (Santo et al. 2011), intervene the sulphide production by injecting oxygen (Gutierrez et al. 2008) and also by using oxygen and caustic simultaneously (Lin et al. 2017).

Along with investigations on MIC, an extensive research has been undertaken to monitor the sulphide production; by inspecting the up take activity of $\mathrm{H}_{2} \mathrm{~S}$ by ANN (Artificial neural network) (Jiang et al. 2016), by non-destructive method (X. Sun et al. 2014), creating a model for sewer corrosion through field and theoretical observations (Wells \& Melchers, 2015), and inhibition techniques for MIC; dissolving the iron salts in sewage for sulfide control (J. Sun et al. 2015; Firer, Friedler, \& Lahav, 2008), use of crown spray (i.e. magnesium hydroxide slurry) to deactivate the sulphate-reducing bacteria and neutralize the acid (Jiang et al. 2014; (Sydney, Esfandi, \& Surapaneni, 1996), removal of dissolved organic carbon for sulphide reaction control (Guang-Hao, Ho-Wai, \& Ju-Chang, 2001), adding Hydrogen peroxide $\left(\mathrm{H}_{2} \mathrm{O}_{2}\right)$ for sulphide control (Joseph et al. 2012), use of nitrate to reduce the accumulation of sulphide (Auguet et al. 2015; Y. Liu et al. 2015; Zheng et al. 2017), use of sulphate free coagulants in drinking water instead of aluminium sulphate (Pikaar et al. 2014) to mitigate the sulphide activity, use of nitrous acid to control sewer corrosion (X. Sun et al. 2015).

In addition to the mitigation and prevention techniques, researches have also been done to modify the RC sewers material to cope with MIC (Grengg et al. 2018; Nielsen et al. 2008; Abraham \& Ali Gillani, 1999); RC sewers made with alumina cement have better resistance to corrosion as compared to ordinary cement (Saucier \& Lamberet, 2009); Alexander \& Fourie, 2011), acid resistant RC sewer pipes (Fourie \& Alexander, 2009), use of inert material (PVC, FRP and HDPE) (Vahidi et al. 2016) as well as pipes urban water management by dislodging the chloride ion by modified cement (Park et al. 2014).

Besides the MIC mitigation techniques; corrosion controlling agents, treatments of sewage and changing in material properties of $\mathrm{RC}$ sewers, protective polymer coating has been found to be a barrier between the sewage chemicals and sewer material ( $\mathrm{Ng} \&$ Kwan, 2015; William Guan, 2001), more proficient and even can influence at micro level on the composition of sewer material (Ling et al. 2014; De Muynck et al. 2008; Fenner, 2000; Ohama, 1995). These coatings reduce the permeability for seepage (Herisson et al. 2016; Valix et al. 2012), decrease ingression of chloride and sulphides (Noeiaghaei et al. 2017; Munger \& Vincent, 1999; Irfan, 1998; Pletcher \& Walsh, 1993), have good chemical and abrasion resistance, exceptional bonding on concrete surface thus contending the corrosion of sewers (Grengg et al. 2018).

Current research focused on the durability and analysis of polyurethane coating against MIC using ASTM C1723 (2010), scanning electron microscopy (SEM) and energy dispersive X-ray analysis (EDAX) (Stutzman, 2001; Jana, 2006). Polyurethane has been found to be effective against the corrosive environment; (Vipulanandan \& Liu, 2005; Guan, 2003) integrates anti-microbial additives and weaken the corrosive environment (De Muynck, De Belie, \& Verstraete, 2009), exceptional bonding with concrete, operative safety, economic, environmental friendly as well as good chemical and abrasion resistance. (Vera et al. 2013; Mobin et al. 2012). 


\section{Experimental Program}

RC sewer Samples were used in this research as well as sewage samples were also obtained from existing waste water streams to present the in-situ conditions. Sewer samples were placed in the sewage whose sulphate concentration was known, and then SEM and EDAX were performed to determine the durability of protective coating against MIC.

\subsection{Materials}

Sewer samples were procured from Public Health Engineering Department (PHED) Khyber Pakhtunkhwa (KPK), Pakistan, which were made according to ASTM C-76 standard. These sewer samples, having thickness of $1.5 \mathrm{in}$ and length of $8 \mathrm{ft}$, were cut down into small pieces approximately 2-3ft each, as shown in fig.1, for testing and analysis purpose then these samples were divided into two categories; sample A and sample B. They were washed and stored in a dry, clean place.
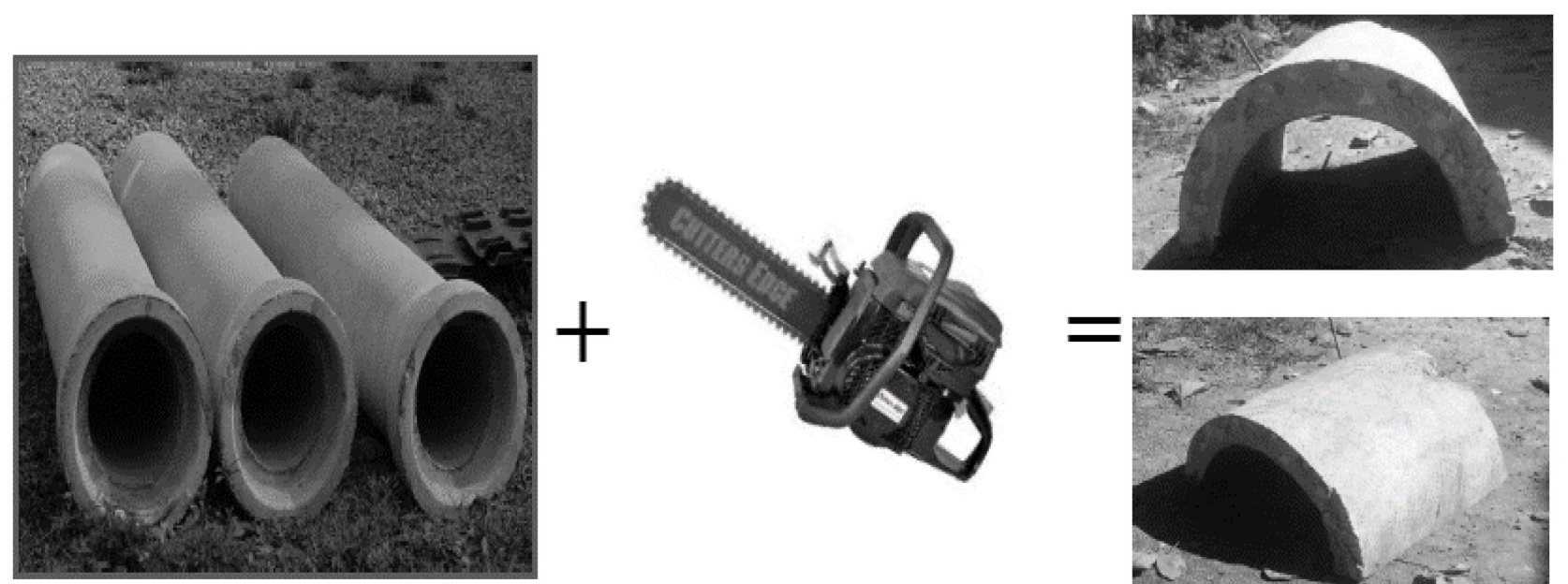

Figure 1. Cutting of Precast Reinforced Concrete Sewer using cutting tool

PEC Sika Seal-105-PK, polyurethane protective coating, comprises of two parts; the grey powder and the white liquid, was used for coating the RC sewer samples. For the preparation of PEC, matrix was kept 1:4 in which one part was white liquid and 4 parts were grey powder as per the preparation instruction of the vendor. Both components were continuously mixed for 2-3 minutes until a smooth thick paste was formed as shown in fig.2. Epoxy coating was applied at different stages with thickness of $2 \mu \mathrm{m}$ and as per the instructions of a coating applicator (Mobin et al. 2012).
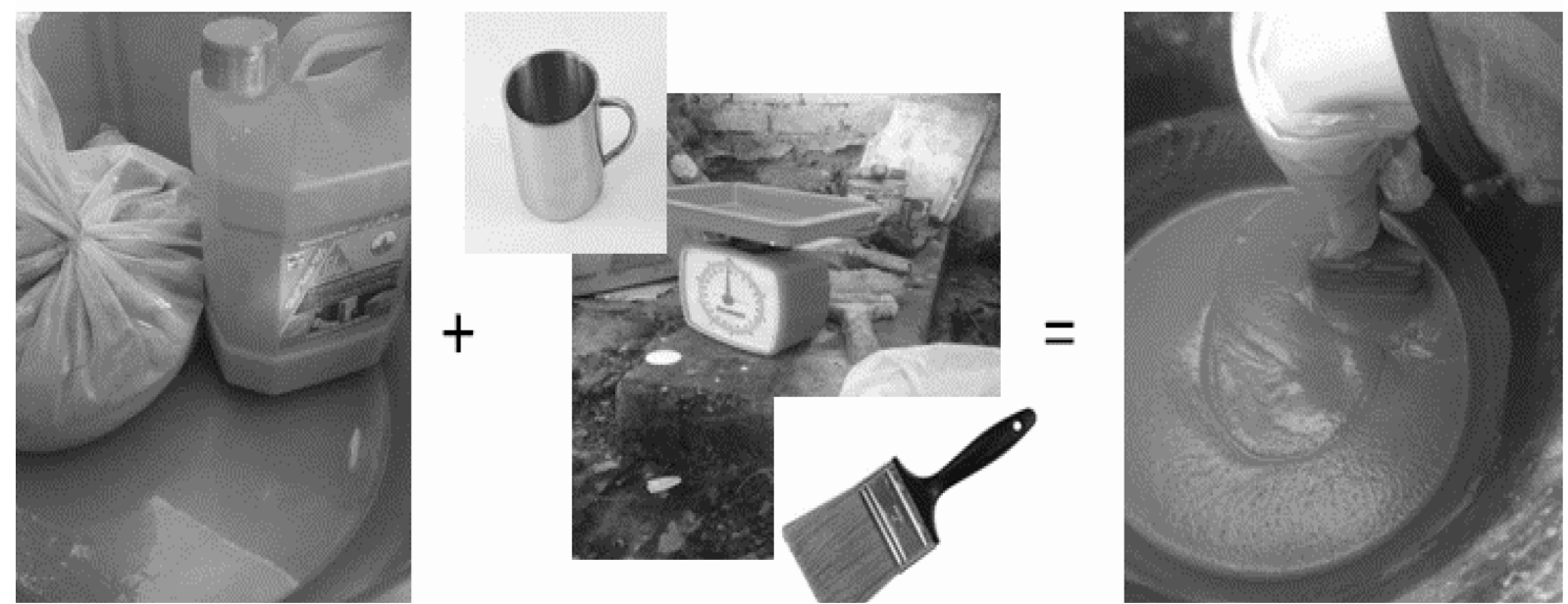

Figure 2. Preparation of epoxy coating 
Sewage was required to chemically attack the samples as in real conditions. Hence, it was collected from two different places; one sample was collected from Khwar, referred as "X" (locally used name for waste water stream) and the other was collected from Hayyatabad Canal located in industrial area, referred as "Y" as shown in fig.3.

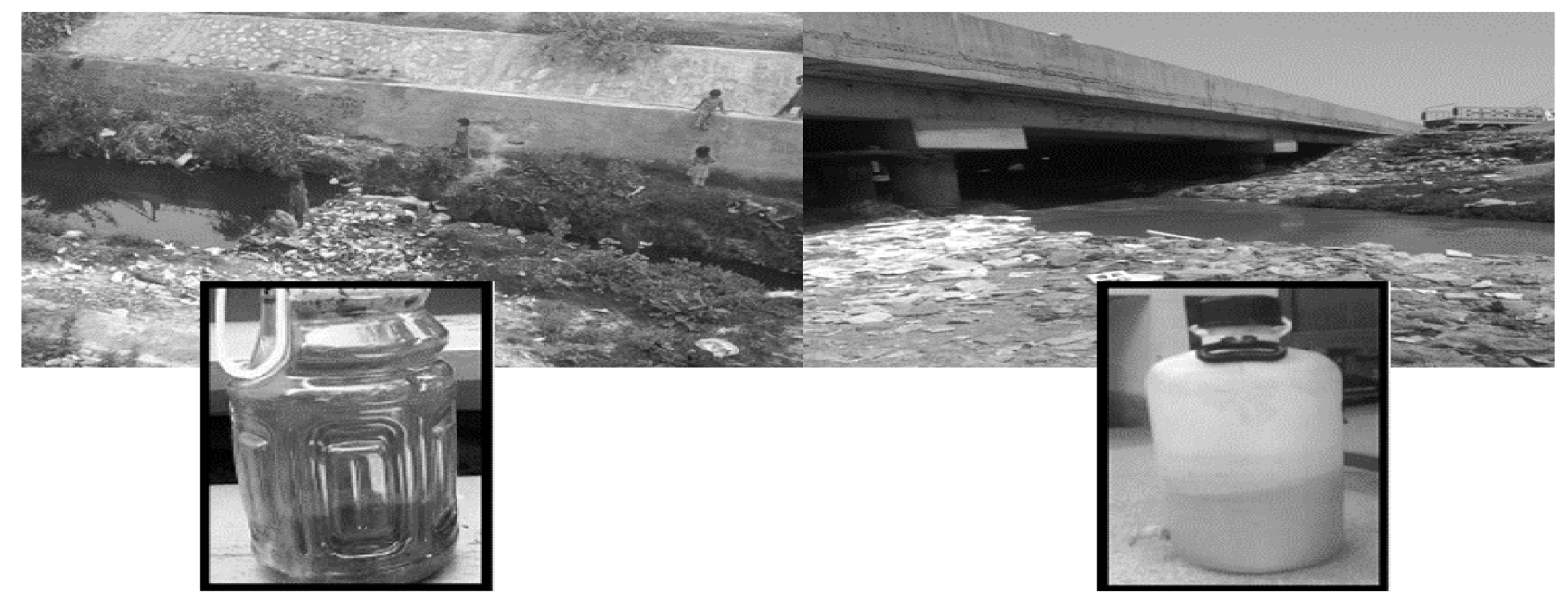

Figure 3. Sewage samples $\mathrm{X}$ and $\mathrm{Y}$ respectively

Sewage samples were filtered through the simple filter paper to remove large suspended particles and then the sulphate content of the sewage samples was calculated using a mass spectrophotometer. The sulphate concentration of sewage sample X came out to be $50 \mathrm{mg} / \mathrm{L}$ and for sewage sample $\mathrm{Y}$, it came out to be $98 \mathrm{mg} / \mathrm{L}$. Sewage sample Y was used to achieve the maximum amount of chemical attacks in minimum possible time.

\subsection{Sample preparation}

\subsubsection{Coating and immersion in sewage}

For the application of PEC on samples; initially RC sewer sample B was taken from the two prepared samples A and B, then sprayed with water to make the surface damp before PEC. The coating was done in two phases on sample B; in first phase, single layer of coating was applied all over the sample with the help of brush and allowed to dry for 6 hours. In second phase, after 6 hours, a second coat was applied all over the sample and allowed to dry as shown in fig.4. (Vera et al. 2013; Mobin et al. 2012).
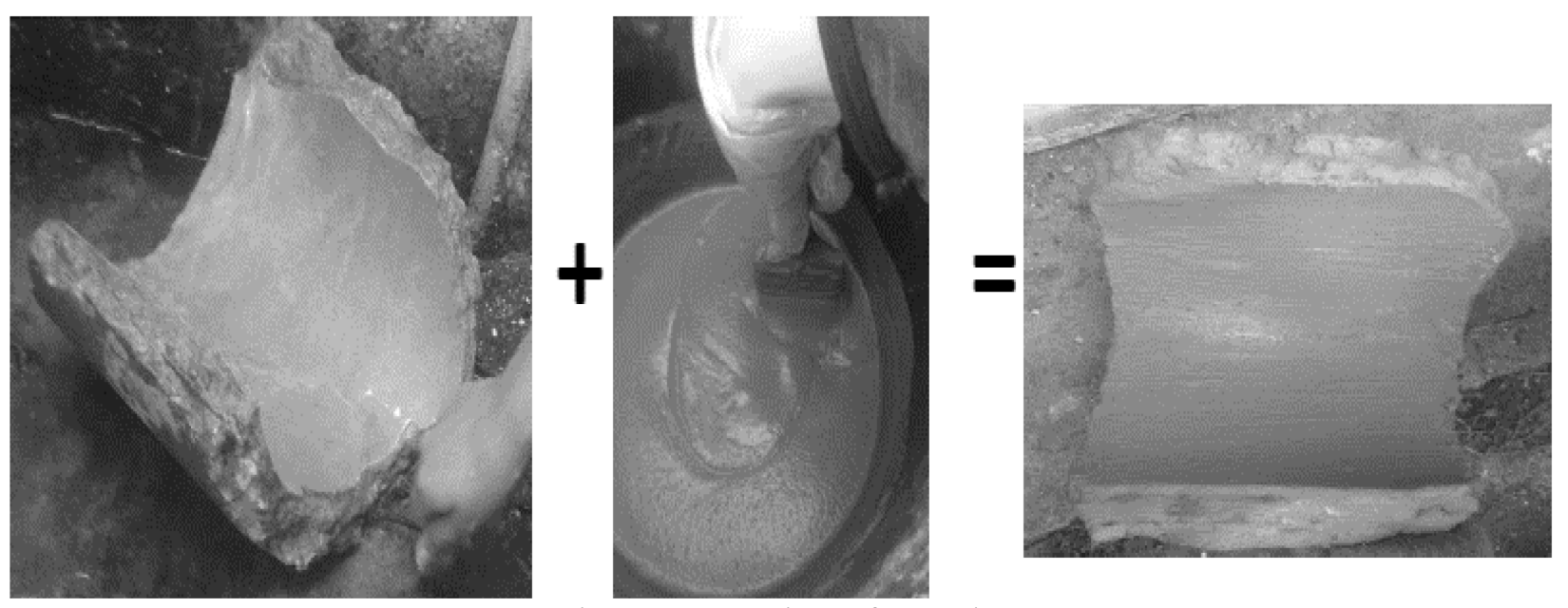

Figure 4. Coating of sample B 
Sample A was first placed in sewage sample "Y" for 30 days and after 30 days of chemical attack, it was washed and dried. A single layer of coating was applied in the same manner as for sample B (Mobin et al. 2012; Grengg et al. 2018).

\subsubsection{In-situ conditions}

The samples prepared were subjected to chemical attack in a specially designed arrangement of plastic containers, containing sewage sample "Y", sealed with plastic covers so that an environment akin to the actual conditions can be provided. Plastic containers were used because of their inertness with the sewage. The duration of chemical attack was 30 and 60 days.

\subsubsection{Sample formulation for microscopic study}

After immersion in sewage sample "Y", sample was prepared for SEM as per the specification of ASTM E2809 (2015) and ASTM C1723 (2010) standard.

The surface of samples was made smooth using grinding machine. To make the corners of the samples already placed on a conductive tape, a silver coating was applied all over the sides of the samples. To remove the excess charge, the samples were sputtered in a gold sputtering machine. After all these steps, the samples were ready to be tested under scanning electron microscope (Jana, 2006; Stutzman, 2001).

\subsection{Testing of samples}

Studying the concrete microstructure of RC sewer through microscopic techniques; SEM, XRD, can enable us to identify the durability problems of concrete and to estimate its service life by the analysis of precipitation; ettringite $\left(\mathrm{Ca}_{6} \mathrm{Al}_{2}\left(\mathrm{SO}_{4}\right)_{3}(\mathrm{OH})_{12} \cdot 26 \mathrm{H}_{2} \mathrm{O}\right)$ (Vera et al. 2013; Mobin et al. 2012). ASTM C1723 (2010) outlines the standard guidelines for examination of hardened concrete using SEM and EDAX.

The microscopic study; SEM AND EDAX, was conducted in two stages on both samples; A and B, simultaneously. Stage:1, sample A (uncoated) and sample B (coated) were placed in the plastic containers with half-filled sewage "Y" in it and chemically attacked for 30 days simultaneously. After 30 days, the microscopic study was carried out on both samples. Stage:2, sample $A_{1}$ (uncoated sample A was coated after 30 days) and sample B (same sample as used in stage-1) were chemically attacked for more 30 days by placing in plastic container having sewage sample "Y". After 60 days, again the microscopic study was carried out on samples.

\section{Analysis and Results}

\subsection{SEM after 30 days of first chemical exposure}

SEM analysis was carried out using scanning electron microscope (JEOL, JED-2300, Japan). It can be observed from fig.5, that the crown portion of the uncoated sample A and coated sample B shows more formation of ettringite (Jiahui, Jianxin, \& Jindong, 2006) as compared to portion of sewer submerged in the sewage. This is because the formation of Sulphuric acid $\left(\mathrm{H}_{2} \mathrm{SO}_{4}\right)$ near the crown portion of the sewer is more.

Also, the ettringite formation in the crown portion of sample A was much more as compared to the crown portion of the coated sample B as shown in fig. 6 because the sample A was uncoated, and the concrete was exposed to the reaction taking place in the sewer. 


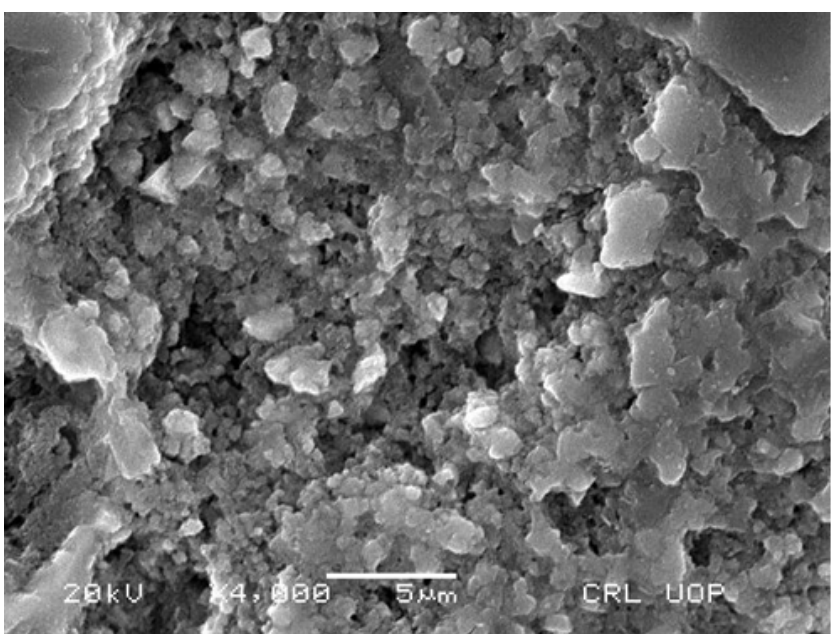

(a)

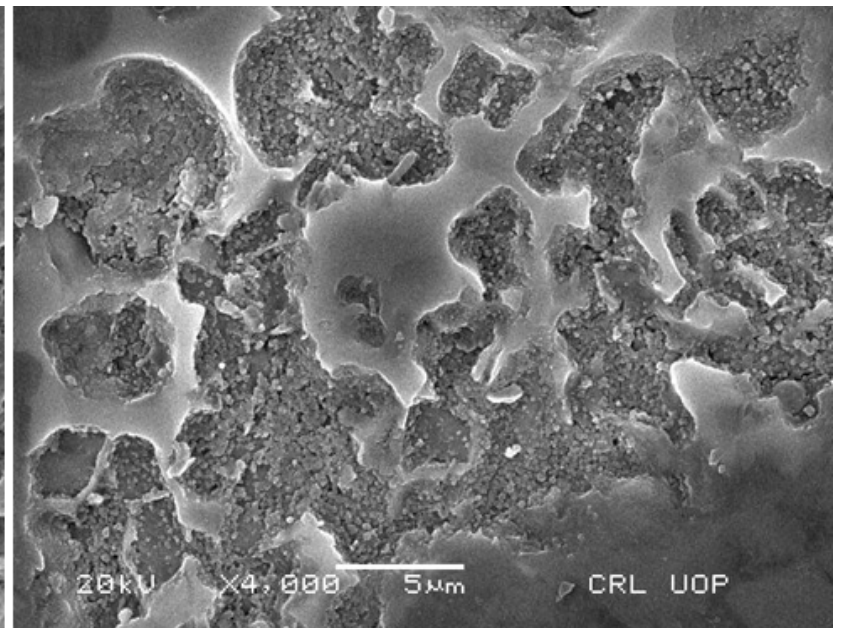

(b)

Figure 5. SEM images (after 30 days) of crown (a) and submerged portion (b) of uncoated sample A

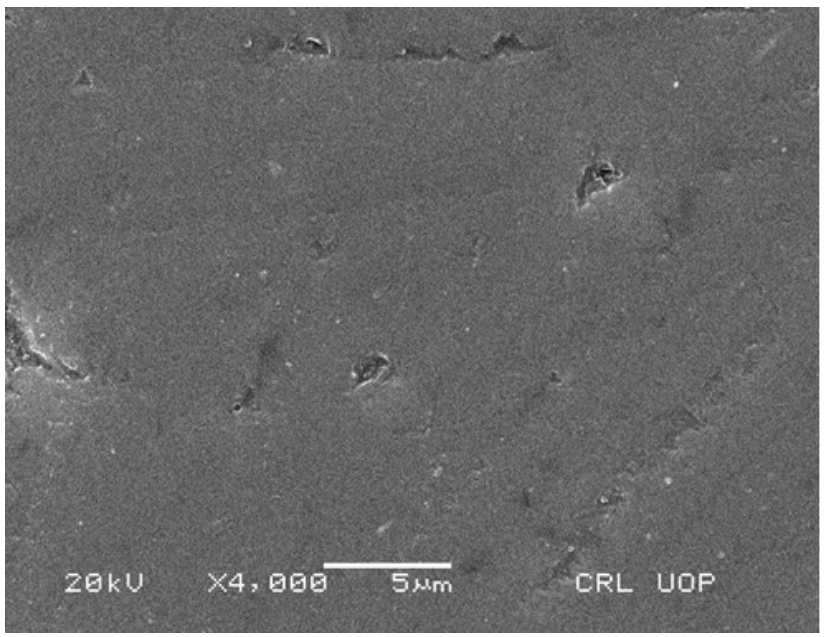

(a)

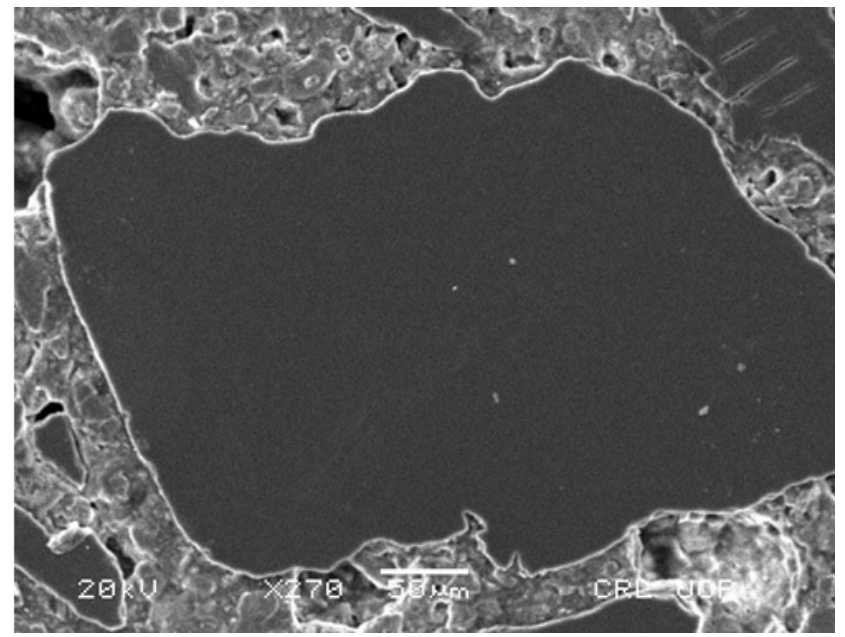

(b)

Figure 6. SEM images (after 30 days) of crown (a) and submerged portion (b) of coated sample B

\subsection{EDAX after 30 Days of First Chemical Exposure}

EDAX was performed simultaneously with the SEM. The graphs clearly show the peaks of precipitations of corrosive components; sulphur peak is more in the crown portion of sample A (uncoated) as compared to submerged portion because the sulphuric acid formation is more in the crown portion as shown in fig.7.

The graphs of sample A show the highest peak of calcium ( $\mathrm{Ca}$ ) because sample is uncoated and calcium is the main component of concrete/cement. Also, the gold ( $\mathrm{Au}$ ) peaks were visible because the samples were spluttered in a gold sputtering machine.

The sample B (coated) show relatively low peaks or negligible peaks of sulphur both for crown and submerged portions because of the coating as shown in fig.8. Also, the silicon peak was observed because it is the main constituent of epoxy coating. 


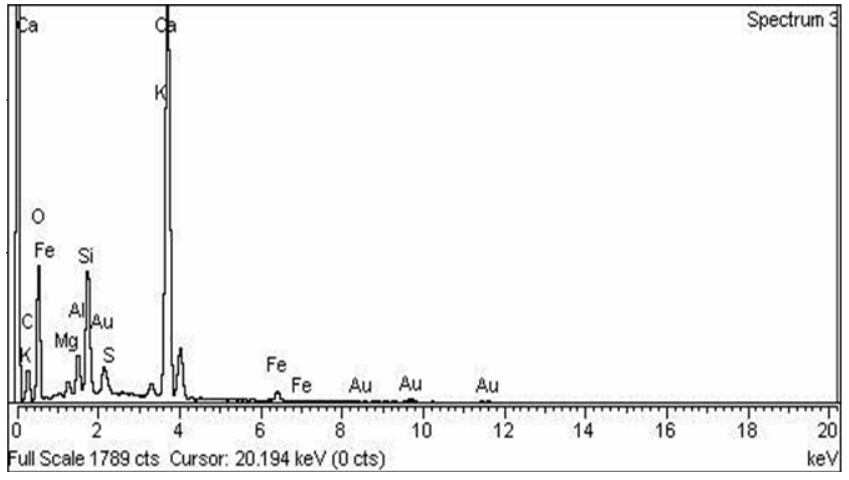

(a)

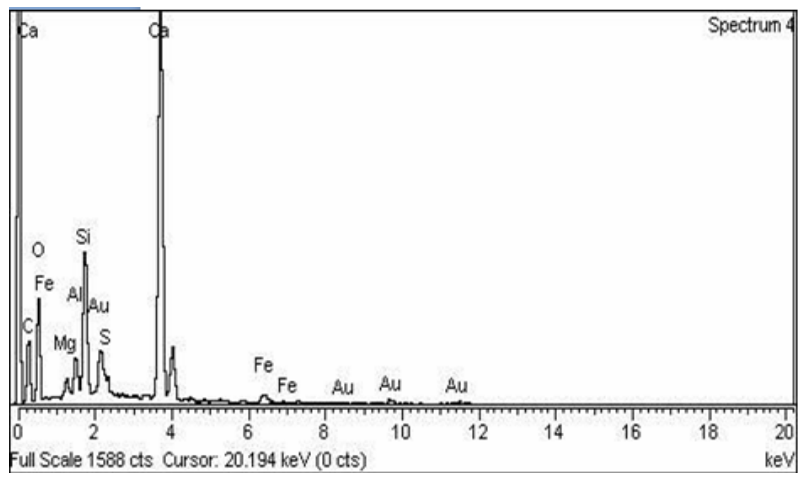

(b)

Figure 7. EDAX graphs (after 30 days) of (a) crown and (b) submerged portion of sample A

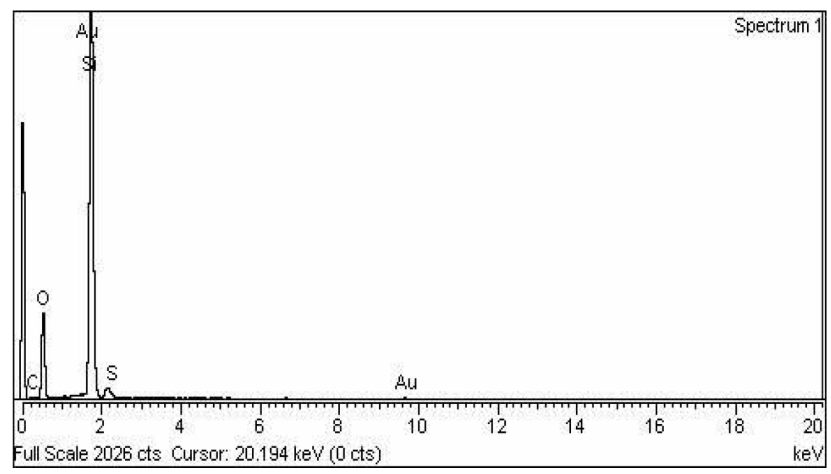

(a)

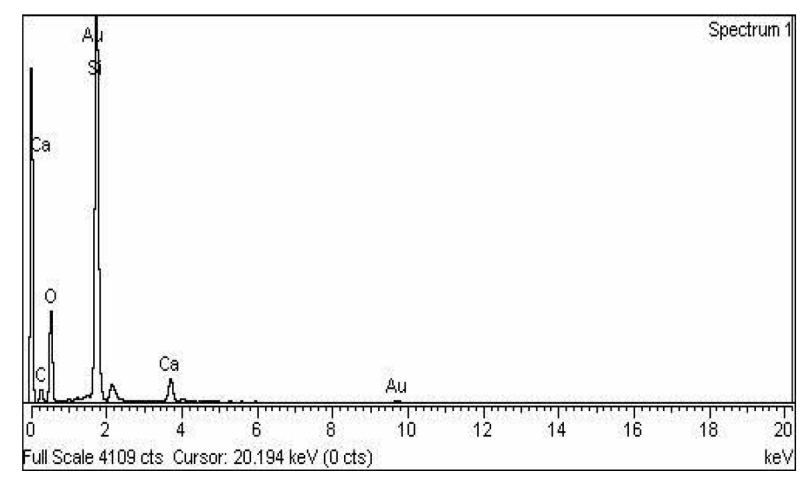

(b)

Figure 8. EDAX graphs (after 30 days) of (a) crown and (b) submerged portion of sample B

\subsection{SEM after 60 days}

The crown portion of sample $A_{1}$ showed more ettringite formation as compared to the submerged portion of the sewer as indicated by fig.9.

Also, the crown portion of coated sample $A_{1}$ showed more ettringite formation as compared to the crown portion of sample B (coated from the beginning; since 60 days) as shown in fig. 10, because the sample $A_{1}$ was initially left uncoated and the reaction already took place in first 30 days of immersion in sewage sample "Y".

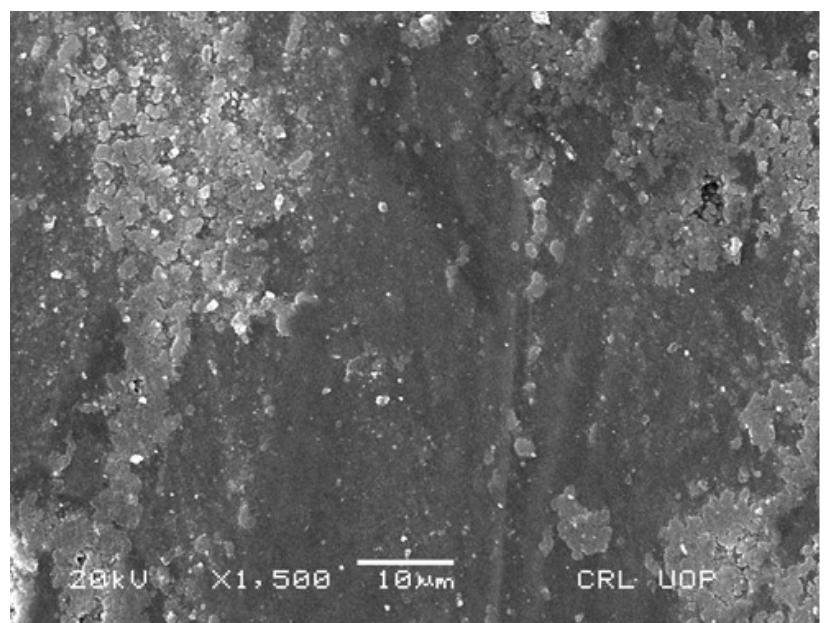

(a)

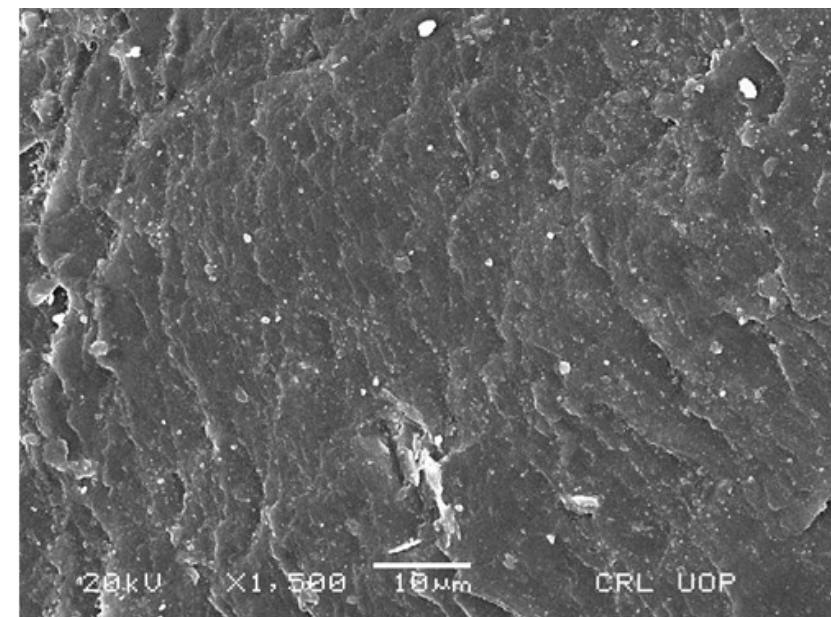

(b)

Figure 9. SEM image (after 60 days) of crown (a) and submerged (b) portion of sample $A_{1}$ 


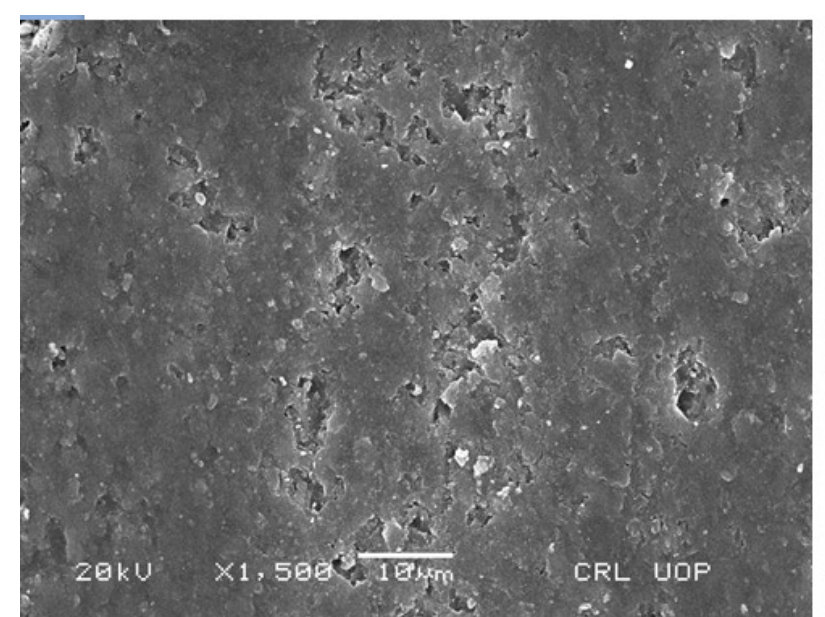

(a)

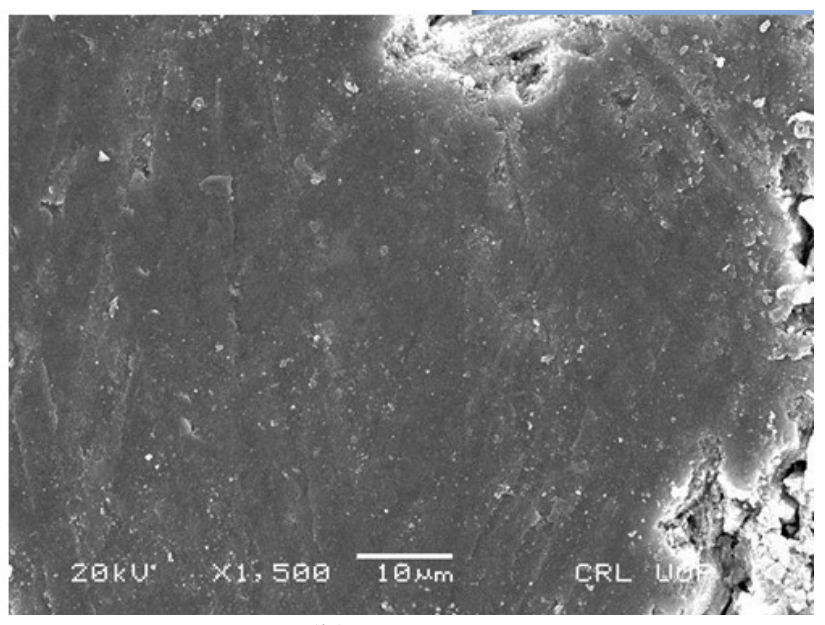

(b)

Figure 10. SEM (after 60 days) images of crown (a) and submerged (b) portion of sample B

\subsection{EDAX after 60 days}

After 60 days, the Sulphur peak of sample $A_{1}$ is lower than that of sample A, showing the decrease in corrosion rate because of the epoxy coating as illustrated in fig.12. Visible peaks of gold $(\mathrm{Au})$ and silicon $(\mathrm{Si})$ are because of gold sputtering and epoxy coatings of the sample.

The crown and submerged portion of sample B show low peaks of the sulphur because it was epoxy coated as shown in fig. 12. The silicon ( $\mathrm{Si}$ ) and gold ( $\mathrm{Au}$ ) peaks appeared because of the epoxy coating and gold sputtering of sample.

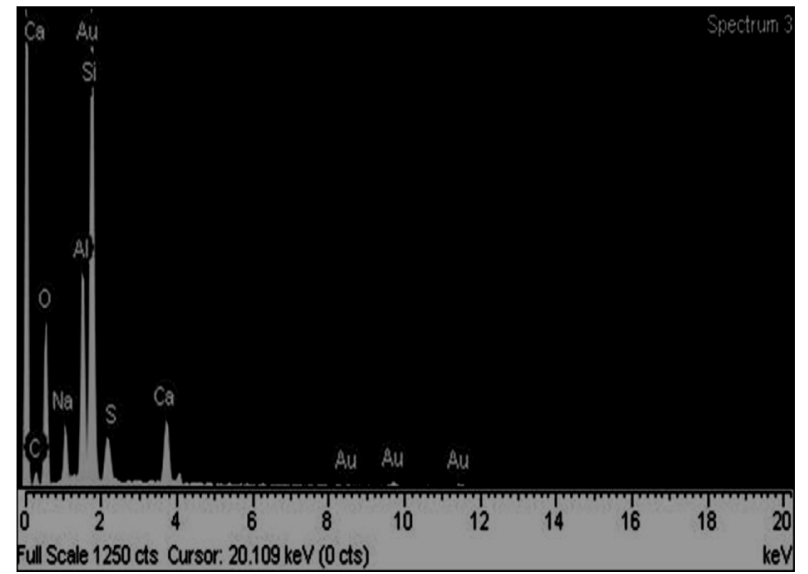

(a)

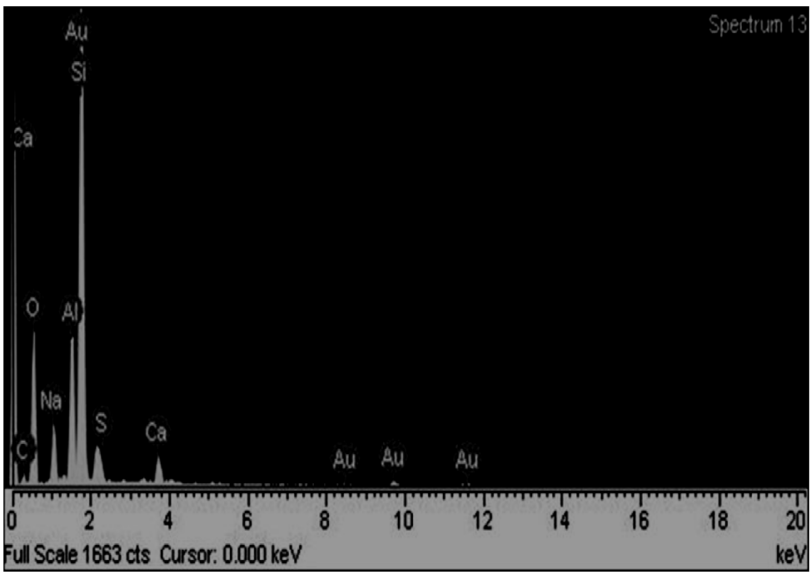

(b)

Figure 11. EDAX graphs (after 60 days) of crown (a) and submerged (b) portion of sample $A_{1}$

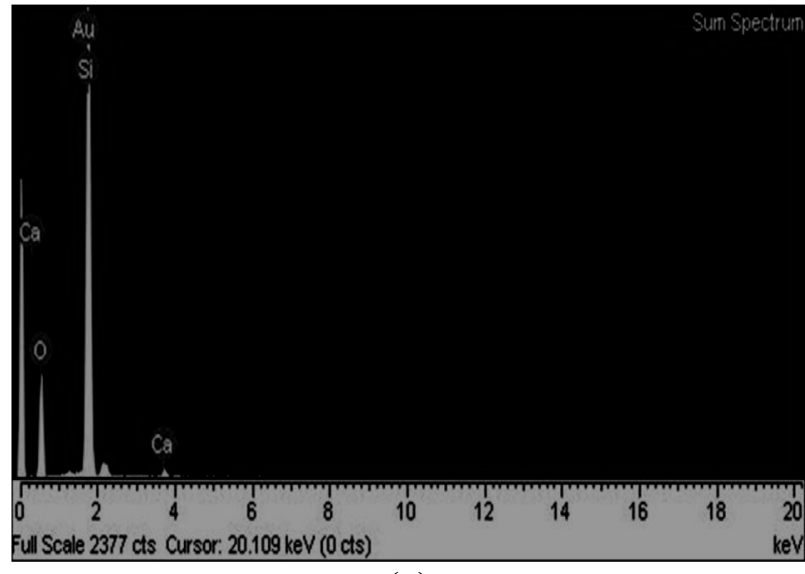

(a)

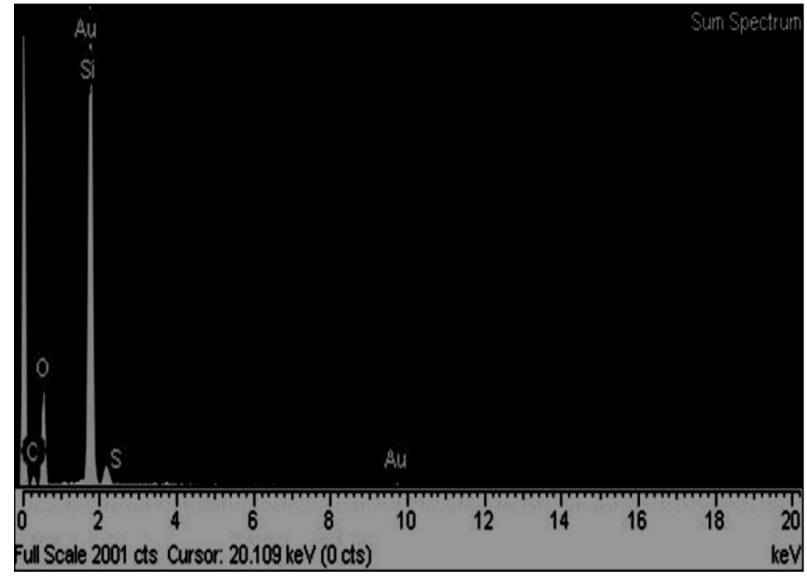

(b)

Figure 12. EDAX graphs (after 60 days) of crown (a) and submerged (b) portion of sample B 


\section{Conclusion}

Based on the results from SEM and EDAX analysis of RC sewer, the following conclusions can be drawn:

- After 30 days of $1^{\text {st }}$ chemical attack, the sample A (uncoated) shows high peaks of corrosive products as compared to sample B (coated).

- After 60 days of chemical attack, sample $A_{1}$ shows less surface precipitation; Sulphur content as compared to sample A because of application of epoxy coating but greater corrosive products than sample B, showing that corrosion had already started in this sample during the initial 30 days when it was left uncoated.

- The sample B has minimum rate of corrosion when compared to sample A and $A_{1}$ at both stages; stage: 1 and stage:2, because of the application of epoxy coating over it.

- The epoxy coatings increase the service life of the sewers by enervating the corrosive environment moreover there is a likelihood that rehabilitated corroded sewers can be reused by applying epoxy coatings over it.

- Because of the limited resources, the experiment was carried out using a standing sewage sample, but It is expected that the gravity flowing sewage, as in actual field conditions, increase the rate of corrosion as compared to the samples placed in standing sewage.

\section{Acknowledgements}

The authors are thankful to the management and staff of Berger Paints Pakistan Limited for their cooperation in providing polyurethane coating for experimental use and for their guidance at different stages of this research.

\section{References}

[1]Abraham, D. M., \& Ali Gillani, S. (1999). Innovations in materials for sewer system rehabilitation. Tunnelling and Underground Space Technology, 14, 43-56. Available at: https://doi.org/https://doi.org/10.1016/S0886-7798(99)00003-6

[2]Alexander, M. G., \& Fourie, C. (2011). Performance of sewer pipe concrete mixtures with portland and calcium aluminate cements subject to mineral and biogenic acid attack. Materials and Structures, 44(1), 313-330. Available at: https://doi.org/10.1617/s11527-010-9629-1

[3]Apté, N., Manager, B., Slurry, S., \& Pcyc, O. (2015). KNOW YOUR SEWER - CORROSION PROTECTION OF SEWER ASSETS Paper Presented by: Nitin Apté Author: Calix Ltd 9 th Annual WIOA NSW Water Industry Operations Conference and Exhibition KNOW YOUR SEWER- CORROSION PROTECTION OF SEWER, (129), 129-135. Available at: http://www.calix.com.au/files/Whitepaper\%20-\%20Know\%20your\%20sewer\%20$\% 20$ Nitin_Apte.pdf

[4]ASTM. (2010). Annual book of ASTM Standards. Standard Specification for Portland Cement (Vol. $\quad$ 0). Available at: http://gostsnip.su/download/astm_c_150_07_standard_specification_for_portland_cement

[5]ASTM. (2015). Standard Guide for Using Scanning Electron Microscopy / X-Ray Spectrometry in. Astm, i, 1-9. Available at: https://doi.org/10.1520/E2809-13.2

[6]ASTM C76-16, Standard Specification for Reinforced Concrete Culvert, Storm Drain, and Sewer Pipe, ASTM International, West Conshohocken, PA, 2016, www.astm.org. Available at: astmc76.pdf. (n.d.).

[7]Auguet, O., Pijuan, M., Guasch-Balcells, H., Borrego, C. M., \& Gutierrez, O. (2015). Implications of Downstream Nitrate Dosage in anaerobic sewers to control sulfide and methane emissions. Water Research, 68, 522-532. Available at: https://doi.org/https://doi.org/10.1016/j.watres.2014.09.034 
[8]Australasian Corrosion Association Inc., T., Melchers, R. E., \& Bond, P. (2012). 49th annual conference of the Australasian Corrosion Association 2009: Corrosion and Prevention 2009, Coffs Harbour, Australia, 15-19 November 2009. 49th Annual Conference of the Australasian Corrosion Association 2009: Corrosion and Prevention 2009. Australasian Corrosion Association. Retrieved from Available at: https://espace.library.uq.edu.au/view/UQ:203250\#.Wm2tlQCs9ig.mendeley

[9]Chapter, B., Corrosion, M. I., Little, B. J., Lee, J. S., \& Division, O. (2009). 2009081403014. (Vol. 18). Available at: www.dtic.mil/get-tr-doc/pdf?AD=ADA503535

[10] De Muynck, W., Cox, K., Belie, N. De, \& Verstraete, W. (2008). Bacterial carbonate precipitation as an alternative surface treatment for concrete. Construction and Building Materials, 22(5), 875-885. Available at: https://doi.org/https://doi.org/10.1016/j.conbuildmat.2006.12.011

[11]De Muynck, W., De Belie, N., \& Verstraete, W. (2009). Effectiveness of admixtures, surface treatments and antimicrobial compounds against biogenic sulfuric acid corrosion of concrete. Cement and Concrete Composites, 31(3), 163-170. Available at: https://doi.org/https://doi.org/10.1016/j.cemconcomp.2008.12.004

[12] Dong, Q., Shi, H., \& Liu, Y. (2017). Microbial Character Related Sulfur Cycle under Dynamic Environmental Factors Based on the Microbial Population Analysis in Sewerage System Frontiers in Microbiology . Available at: https://www.ncbi.nlm.nih.gov/pmc/articles/PMC5306501/

[13]E., H., M., N., E., A., \& G., N. (2007). Effect of Mixture Design Parameters and Wetting-Drying Cycles on Resistance of Concrete to Sulfuric Acid Attack. Journal of Materials in Civil Engineering, 19(2), 155-163. Available at: https://doi.org/10.1061/(ASCE)08991561(2007)19:2(155)

[14] Fenner, R. A. (2000). Approaches to sewer maintenance: a review. Urban Water, 2(4), 343-356. Available at: https://doi.org/https://doi.org/10.1016/S1462-0758(00)00065-0

[15]Firer, D., Friedler, E., \& Lahav, O. (2008). Control of sulfide in sewer systems by dosage of iron salts: Comparison between theoretical and experimental results, and practical implications. Science of The Total Environment, 392(1), 145-156. Available at: https://doi.org/https://doi.org/10.1016/j.scitotenv.2007.11.008

[16] Fourie, C. W., \& Alexander, M. G. (2009). Acid resistant concrete sewer pipes. In Proceedings of the International RILEM TC-211 PAE Final Conference (pp. 408-418). Available at: http://www.civil.uct.ac.za/usr/civeng/staff/pilate-publications.pdf

[17] Gemert, A. B. and D. Van. (n.d.). Biogenic Sulphuric Acid Attack of Concrete Sewer Pipes: A Prediction of the Corrosion Rate. Special Publication, 200. Available at: https://doi.org/10.14359/10604

[18] Grengg, C., Mittermayr, F., Ukrainczyk, N., Koraimann, G., Kienesberger, S., \& Dietzel, M. (2018). Advances in concrete materials for sewer systems affected by microbial induced concrete corrosion: A review. Water Research, 134, 341-352. Available at: https://doi.org/https://doi.org/10.1016/j.watres.2018.01.043

[19] Guan, W. S. (2003). Advanced 100\% Solids Rigid Polyurethane Coatings Technology for Pipeline Field Joints and Rehabilitation. CORROSION 2003. Available at: http://eprints.nmlindia.org/4182/1/98-103.PDF

[20] Guang-Hao, C., Ho-Wai, L. D., \& Ju-Chang, H. (2001). Removal of Dissolved Organic Carbon in Sanitary Gravity Sewer. Journal of Environmental Engineering, 127(4), 295-301. Available at: https://doi.org/10.1061/(ASCE)0733-9372(2001)127:4(295)

[21] Gutierrez, O., Mohanakrishnan, J., Sharma, K. R., Meyer, R. L., Keller, J., \& Yuan, Z. (2008). Evaluation of oxygen injection as a means of controlling sulfide production in a sewer system. Water Research, 42(17), 4549-4561. Available at: https://doi.org/https://doi.org/10.1016/j.watres.2008.07.042

[22] Herisson, J., Guéguen-Minerbe, M., van Hullebusch, E. D., \& Chaussadent, T. (2016). Influence of the binder on the behaviour of mortars exposed to H2S in sewer networks: a long-term durability study. Materials and Structures, 50(1), 8. Available at: https://doi.org/10.1617/s11527-016-09190 
[23] Hewayde, E., Nehdi, M., Allouche, E., \& Nakhla, G. (2006). Effect of geopolymer cement on microstructure, compressive strength and sulphuric acid resistance of concrete. Magazine of Concrete Research, 58(5), 321-331. Available at: https://doi.org/10.1680/macr.2006.58.5.321

[24] Irfan, M. H. (1998). Polyurethanes in the construction industry BT - Chemistry and Technology of Thermosetting Polymers in Construction Applications. In M. H. Irfan (Ed.) (pp. 123-144). Dordrecht: Springer Netherlands. Available at: https://doi.org/10.1007/978-94-011-4954-9 4

[25] Islander, B. R. L., Devinny, J. S., Member, A., Mansfeld, F., Postyn, A., \& Shih, H. (1992). Microbial e c o 1 o g y o f c $\mathrm{r}$ o w n corrosion in sewers, 117(6), 751-770. Available at: https://ascelibrary.org/doi/abs/10.1061/\%28ASCE\%290733-

9372\%281991\%29117\%3A6\%28751\%29

[26] Jana, D. (2006). Sample preparation techniques in petrographic examinations of construction materials: A state-of-the-art review. In Proceedings of the twenty-eighth Conference on Cement Microscopy (p. 48). Available at: https://www.scribd.com/document/157072301/2006-SamplePreparation-Techniques-28th-ICMA

[27] Jiahui, P., Jianxin, Z., \& Jindong, Q. (2006). The mechanism of the formation and transformation of ettringite. Journal of Wuhan University of Technology-Mater. Sci. Ed., 21(3), 158-161. Available at: https://doi.org/10.1007/BF02840908

[28] Jiang, G., Keller, J., Bond, P. L., \& Yuan, Z. (2016). Predicting concrete corrosion of sewers using artificial neural network. Water Research, 92, 52-60. Available at: https://doi.org/10.1016/j.watres.2016.01.029

[29] Jiang, G., Sun, J., Sharma, K. R., \& Yuan, Z. (2015). Corrosion and odor management in sewer systems. Current Opinion in Biotechnology, 33, 192-197. Available at: https://doi.org/https://doi.org/10.1016/j.copbio.2015.03.007

[30] Jiang, G., Sun, X., Keller, J., \& Bond, P. L. (2015). Identification of controlling factors for the initiation of corrosion of fresh concrete sewers. Water Research, 80, 30-40. Available at: https://doi.org/https://doi.org/10.1016/j.watres.2015.04.015

[31] Jiang, G., Wightman, E., Donose, B. C., Yuan, Z., Bond, P. L., \& Keller, J. (2014). The role of iron in sulfide induced corrosion of sewer concrete. Water Research, 49, 166-174. Available at: https://doi.org/10.1016/j.watres.2013.11.007

[32] Jiang, G., Zhou, M., Chiu, T. H., Sun, X., Keller, J., \& Bond, P. L. (2016). Wastewater-Enhanced Microbial Corrosion of Concrete Sewers. Environmental Science \& Technology, 50(15), 80848092. Available at: https://doi.org/10.1021/acs.est.6b02093

[33] Joseph, A. P., Keller, J., Bustamante, H., \& Bond, P. L. (2012). Surface neutralization and H2S oxidation at early stages of sewer corrosion: Influence of temperature, relative humidity and $\mathrm{H} 2 \mathrm{~S}$ concentration. Water Research, 46(13), 4235-4245. Available at: https://doi.org/https://doi.org/10.1016/j.watres.2012.05.011

[34] Kuliczkowska, E. (2016). Risk of structural failure in concrete sewers due to internal corrosion. Engineering Failure Analysis, 66, 110-119. Available at: https://doi.org/https://doi.org/10.1016/j.engfailanal.2016.04.026

[35]Lin, H.-W., Lu, Y., Ganigué, R., Sharma, K. R., Rabaey, K., Yuan, Z., \& Pikaar, I. (2017). Simultaneous use of caustic and oxygen for efficient sulfide control in sewers. Science of The Total Environment, 601-602, 776-783. Available at: https://doi.org/https://doi.org/10.1016/j.scitotenv.2017.05.225

[36]Ling, A. L., Robertson, C. E., Harris, J. K., Frank, D. N., Kotter, C. V, Stevens, M. J., ... Hernandez, M. T. (2014). Carbon Dioxide and Hydrogen Sulfide Associations with Regional Bacterial Diversity Patterns in Microbially Induced Concrete Corrosion. Environmental Science \& Technology, 48(13), 7357-7364. Available at: https://doi.org/10.1021/es500763e

[37]Liu, Y., Ni, B.-J., Ganigué, R., Werner, U., Sharma, K. R., \& Yuan, Z. (2015). Sulfide and methane production in sewer sediments. Water Research, 70, 350-359. Available at: https://doi.org/https://doi.org/10.1016/j.watres.2014.12.019

[38]Liu, Y., Sharma, K. R., Ni, B.-J., Fan, L., Murthy, S., Tyson, G. Q., \& Yuan, Z. (2015). Effects of nitrate dosing on sulfidogenic and methanogenic activities in sewer sediment. Water Research, 74, 155-165. Available at: https://doi.org/https://doi.org/10.1016/j.watres.2015.02.017 
[39] Meyer, A. H., \& Ledbetter, W. B. (n.d.). Sulfuric acid attack on concrete sewer pipe. Journal of the Sanitary Engineering Division, 96(5), 1167-1182. Available at: http://cedb.asce.org/CEDBsearch/record.jsp?dockey $=0017277$

[40] Mobin, M., Malik, A. U., Al-Muaili, F., \& Al-Hajri, M. (2012). Performance evaluation of a commercial polyurethane coating in marine environment. Journal of Materials Engineering and Performance, 21(7), 1292-1299. Available at: https://doi.org/10.1007/s11665-011-0034-

[41] Munger, C. G., \& Vincent, L. D. (1999). Corrosion protection by protective coatings (2nd ed.). Houston Tex.: National Association of Corrosion Engineers. Retrieved from http://www.worldcat.org/title/corrosion-prevention-by-protectivecoatings/oclc/964731722? referer=di\&ht=edition\#.Wm4uIRT71xQ.mendeley

[42]Ng, P. L., \& Kwan, A. K. H. (2015). Improving Concrete Durability for Sewerage Applications BT - Engineering Asset Management - Systems, Professional Practices and Certification. In P. W. Tse, J. Mathew, K. Wong, R. Lam, \& C. N. Ko (Eds.) (pp. 1043-1053). Cham: Springer International Publishing. Available at: https://ink.springer.com/book/10.1007\%2F978-3-31909507-3

[43] Nielsen, A. H., Vollertsen, J., Jensen, H. S., Wium-Andersen, T., \& Hvitved-Jacobsen, T. (2008). Influence of pipe material and surfaces on sulfide related odor and corrosion in sewers. Water Research, 42(15), 4206-4214. https://doi.org/https://doi.org/10.1016/j.watres.2008.07.013

[44] Noeiaghaei, T., Mukherjee, A., Dhami, N., \& Chae, S.-R. (2017). Biogenic deterioration of concrete and its mitigation technologies. Construction and Building Materials, 149, 575-586. Available at: https://doi.org/https://doi.org/10.1016/j.conbuildmat.2017.05.144

[45] O 'connell, M. ; Mcnally, C. ;, Richardson, M. G., 'connell, O., Mcnally, M., \& Richardson, M. G. (2010). Title Biochemical attack on concrete in wastewater applications : a state of the art review Biochemical Attack on Concrete in Wastewater Applications: A State of the Art Review. Cement and Concrete Composites, 32(7), 0-21. Available at: https://doi.org/10.1016/j.cemconcomp.2010.05.001

[46] Ohama, Y. (1995a). 5 - Fabrication and Properties of Redispersible Polymer Powder-Modified Systems BT - Handbook of Polymer-Modified Concrete and Mortars (pp. 157-174). Park Ridge, NJ: William Andrew Publishing. Available at: https://doi.org/https://doi.org/10.1016/B978081551358-2.50006-2

[47] Ohama, Y. (1995b). 6 - Fabrication and Properties of Water-Soluble Polymer-Modified Systems BT - Handbook of Polymer-Modified Concrete and Mortars (pp. 175-182). Park Ridge, NJ: William Andrew Publishing. Available at: https://doi.org/https://doi.org/10.1016/B978081551358-2.50007-4

[48] Ohama, Y. (1995c). 7 - Fabrication and Properties of Liquid Resin and Monomer-Modified Systems BT - Handbook of Polymer-Modified Concrete and Mortars (pp. 183-204). Park Ridge, NJ: William Andrew Publishing. Available at: https://doi.org/https://doi.org/10.1016/B978081551358-2.50008-6

[49] Ohama, Y. (1995d). 8 - Special Polymer-Modified Systems BT - Handbook of PolymerModified Concrete and Mortars (pp. 205-221). Park Ridge, NJ: William Andrew Publishing. Available at: https://doi.org/https://doi.org/10.1016/B978-081551358-2.50009-8

[50] Okabe, S., Odagiri, M., Ito, T., \& Satoh, H. (2007). Succession of Sulfur-Oxidizing Bacteria in the Microbial Community on Corroding Concrete in Sewer Systems . Applied and Environmental Microbiology, 73(3), 971-980. Available at: https://doi.org/10.1128/AEM.02054-06

[51] Parande, A. K., Ramsamy, P. L., Ethirajan, S., Rao, C. R. K., \& Palanisamy, N. (2006). Deterioration of reinforced concrete in sewer environments. Proceedings of the Institution of Civil Engineers - Municipal Engineer, 159(1), 11-20. Available at: https://doi.org/10.1680/muen.2006.159.1.11

[52] Park, K., Lee, H., Phelan, S., Liyanaarachchi, S., Marleni, N., Navaratna, D., ... Shu, L. (2014). Mitigation strategies of hydrogen sulphide emission in sewer networks - A review. International Biodeterioration \& Biodegradation, 95, 251-261. Available at: https://doi.org/https://doi.org/10.1016/j.ibiod.2014.02.013 
[53] Parker, C. D. (1951). Mechanics of Corrosion of Concrete Sewers by Hydrogen Sulfide. Sewage and Industrial Wastes, 23(12), 1477-1485. Retrieved from http://www.jstor.org/stable/25031769

[54] PARKER, C. D. (1947). Species of Sulphur Bacteria Associated with the Corrosion of Concrete. Nature, 159, 439. Retrieved from http://dx.doi.org/10.1038/159439b0

[55] Pikaar, I., Sharma, K. R., Hu, S., Gernjak, W., Keller, J., \& Yuan, Z. (2014). Reducing sewer corrosion through integrated urban water management. Science, 345(6198), 812 LP-814. Retrieved from http://science.sciencemag.org/content/345/6198/812.abstract

[56] Pletcher, D., \& Walsh, F. C. (1993). Corrosion and its control BT - Industrial Electrochemistry. In D. Pletcher \& F. C. Walsh (Eds.) (pp. 481-542). Dordrecht: Springer Netherlands. Available at: https://doi.org/10.1007/978-94-011-2154-5_10

[57] Santo Domingo, J. W., Revetta, R. P., Iker, B., Gomez-Alvarez, V., Garcia, J., Sullivan, J., \& Weast, J. (2011). Molecular survey of concrete sewer biofilm microbial communities. Biofouling, 27(9), 993-1001. Available at: https://doi.org/10.1080/08927014.2011.618637

[58] Saucier, F., \& Lamberet, S. (2009). Calcium aluminate concrete for sewers: going from qualitative to quantitative evidence of performance. In Proceedings of the international RILEM TC-211 PAE final conference, Toulouse (pp. 398-407). Available at: demo.webdefy.com/rilemnew/wp-content/uploads/2016/10/pro063-040.pdf

[59] Sharma, K. R., Yuan, Z., de Haas, D., Hamilton, G., Corrie, S., \& Keller, J. (2008). Dynamics and dynamic modelling of H2S production in sewer systems. Water Research, 42(10), 2527-2538. Available at: https://doi.org/https://doi.org/10.1016/j.watres.2008.02.013

[60] Stutzman, P. E. (2001). Scanning Electron Microscopy in Concrete Petrography. Materials Science of Concrete Special Volume, 59-72. Retrieved from Available at: http://fire.nist.gov/bfrlpubs/build01/PDF/b01086.pdf

[61] Sulikowski, J., \& Kozubal, J. (2016). The Durability of a Concrete Sewer Pipeline under Deterioration by Sulphate and Chloride Corrosion. Procedia Engineering, 153, 698-705. Available at: https://doi.org/https://doi.org/10.1016/j.proeng.2016.08.229

[62] Sun, J., Pikaar, I., Sharma, K. R., Keller, J., \& Yuan, Z. (2015). Feasibility of sulfide control in sewers by reuse of iron rich drinking water treatment sludge. Water Research, 71, 150-159. Available at: https://doi.org/https://doi.org/10.1016/j.watres.2014.12.044

[63] Sun, X., Jiang, G., Bond, P. L., \& Keller, J. (2015). Impact of fluctuations in gaseous H2S concentrations on sulfide uptake by sewer concrete: The effect of high H2S loads. Water Research, 81, 84-91. Available at: https://doi.org/https://doi.org/10.1016/j.watres.2015.05.044

[64] Sun, X., Jiang, G., Bond, P. L., Keller, J., \& Yuan, Z. (2015). A novel and simple treatment for control of sulfide induced sewer concrete corrosion using free nitrous acid. Water Research, 70, 279-287. Available at: https://doi.org/https://doi.org/10.1016/j.watres.2014.12.020

[65] Sun, X., Jiang, G., Bond, P. L., Wells, T., \& Keller, J. (2014). A rapid, non-destructive methodology to monitor activity of sulfide-induced corrosion of concrete based on H2S uptake rate. Water Research, 59, 229-238. Available at: https://doi.org/10.1016/j.watres.2014.04.016

[66] Sydney, R., Esfandi, E., \& Surapaneni, S. (1996). Control concrete sewer corrosion via the crown spray process. Water Environment Research, 68(3), 338-347. Available at: https://doi.org/10.2175/106143096X127785

[67] Taylor, C. B., \& Hutchinson, G. H. (1947). Corrosion of concrete caused by sulphur-oxidising bacteria. Journal of the Society of Chemical Industry, 66(2), 54-57. Available at: https://doi.org/10.1002/jctb.5000660205

[68] Vahidi, E., Jin, E., Das, M., Singh, M., \& Zhao, F. (2016). Environmental life cycle analysis of pipe materials for sewer systems. Sustainable Cities and Society, 27, 167-174. Available at: https://doi.org/https://doi.org/10.1016/j.scs.2016.06.028

[69] Valix, M., Zamri, D., Mineyama, H., Cheung, W. H., Shi, J., \& Bustamante, H. (2012). Microbiologically induced corrosion of concrete and protective coatings in gravity sewers. Chinese Journal of Chemical Engineering, 20(3), 433-438. Available at: https://doi.org/10.1016/S1004-9541(11)60150-X 
[70] Vera, R. ., Apablaza, J. ., Carvajal, A. M. ., \& Vera, E. . (2013). Effect of surface coatings in the corrosion of reinforced concrete in acid environments. International Journal of Electrochemical Science, 8(10), 11832-11846. Retrieved from Available at: http://www.scopus.com/inward/record.url?eid=2-s2.084886494628\&partnerID $=40 \& \mathrm{md} 5=45 \mathrm{e} 8250 \mathrm{ee} 310776270 \mathrm{f} 941 \mathrm{a} 274 \mathrm{f} 2279 \mathrm{e}$

[71] Vipulanandan, C., \& Liu, J. (2005). Performance of polyurethane-coated concrete in sewer environment. Cement and Concrete Research, 35(9), 1754-1763. Available at: https://doi.org/10.1016/j.cemconres.2004.10.033

[72] Wei, S., Jiang, Z., Liu, H., Zhou, D., \& Sanchez-Silva, M. (2013). Microbiologically induced deterioration of concrete - A review. Brazilian Journal of Microbiology, 44(4), 1001-1007. Available at: https://doi.org/10.1590/S1517-83822014005000006

[73] Wells, T., \& Melchers, R. E. (2015). Modelling concrete deterioration in sewers using theory and field observations. Cement and Concrete Research, 77, 82-96. Available at: https://doi.org/https://doi.org/10.1016/j.cemconres.2015.07.003

[74] William Guan, S. (2001). Corrosion Protection By Coatings for Water and Wastewater Pipelines, 1-28. Available at: https://www.chlor rid.com/saltinfo/links/Pipeline\%20Corrosion\%20Protection\%20by\%20Guan\%20page\%2017.pdf

[75]Zhang, L., De Schryver, P., De Gusseme, B., De Muynck, W., Boon, N., \& Verstraete, W. (2008a). Chemical and biological technologies for hydrogen sulfide emission control in sewer systems: A review. Water Research, 42(1), 1-12. Available at: https://doi.org/https://doi.org/10.1016/j.watres.2007.07.013

[76]Zhang, L., De Schryver, P., De Gusseme, B., De Muynck, W., Boon, N., \& Verstraete, W. (2008b). Chemical and biological technologies for hydrogen sulfide emission control in sewer systems: A review. Water Research, 42(1-2), 1-12. Available at: https://doi.org/10.1016/j.watres.2007.07.013

[77]Zheng, M., Zuo, Z., Zhang, Y., Cui, Y., Dong, Q., Liu, Y., ... Yuan, Z. (2017). Nitrite production from urine for sulfide control in sewers. Water Research, 122, 447-454. Available at: https://doi.org/https://doi.org/10.1016/j.watres.2017.05.048 